\title{
Using an Audiovisual Materials-Based Teaching Strategy to Improve EFL Young Learners' Understanding of Instructions
}

\section{Uso de una estrategia de enseñanza sustentada en material audiovisual para el mejoramiento de la comprensión de instrucciones en niños que aprenden inglés como lengua extranjera*}

\author{
Gemalli Ulloa Salazar \\ geulloa@udec.cl \\ Claudio Díaz Larenas \\ claudiodiaz@udec.cl \\ Universidad de Concepción, Concepción, Chile
}

Conducted in a semi-public school in Chile, this action research study aims at determining the change in 18 English as a foreign language young learners' performance regarding their understanding of instructions after being exposed to an audiovisual materials-based teaching strategy. With the use of a lesson observation report for assessing the way they follow instructions and a Likert scale to analyze their attitudes towards the strategy, findings show there was a positive change in their performances and that these learners regard this strategy as beneficial, which supports the belief that the inclusion of audiovisual aids benefits young learners when learning English.

This paper is part of the research grant FONDECYT 1150889: "Las dimensiones cognitivas, afectivas y sociales del proceso de planificación de aula y su relación con los desempeños pedagógicos en estudiantes de práctica profesional y profesores nóveles de pedagogía en inglés".

Received: October 1, 2017. Accepted: March 4, 2018.

How to cite this article (APA 6th ed.):

Ulloa Salazar, G., \& Díaz Larenas, C. (2018). Using an audiovisual materials-based teaching strategy to improve EFL young learners' understanding of instructions. HOW, 25(2), 91-112. https://doi.org/10.19183/ how.25.2.419.

This article is licensed under a Creative Commons Attribution-NonCommercial-NoDerivatives 4.0 International License. License Deed can be consulted at https://creativecommons.org/licenses/by-nc-nd/4.0/. 
Key words: Audiovisual materials, modelling, young learners.

Realizada en una escuela semi-pública en Chile, esta investigación acción tiene como objetivo determinar el cambio en el desempeño de dieciocho estudiantes jóvenes de inglés como lengua extranjera en cuanto a su comprensión de instrucciones luego de estar expuestos a una estrategia pedagógica basada en material audiovisual. Con el uso de un reporte de observación de clases para evaluar la forma en la que siguen instrucciones y una escala de Likert para analizar sus actitudes en cuanto a la estrategia, los resultados muestran que hubo un cambio positivo en su desempeño y que estos estudiantes consideran esta estrategia como beneficiosa, lo que apoya la creencia de que la inclusión de apoyo audiovisual beneficia a los estudiantes al aprender inglés.

Palabras clave: estudiantes jóvenes, materiales audiovisuales, modelar.

\section{Introduction}

We live in a world surrounded by media and visual stimuli, and so are children, who are part of the digital generation (Jukes, McCain, \& Crockett, 2010). In Chile, a great percentage of the young learners in the school system are part of this generation, yet this is not always considered. Teachers of English in the country have struggled to embrace technology as an aid in their lessons, even when researchers have stated that using audiovisual materials can benefit learners and teachers (Daniel, 2013), especially if we include them in aspects such as instructions or lessons routines.

Moreover, not every school in the country offers English from kindergarten to fourth grade, since it is not compulsory. Although learning English at an early age does not assure acquisition if other factors are not considered (Lightbown \& Spada, 2013), it does have some benefits, as some researchers state (Cameron, 2001; Curtain \& Dahlberg, 2010; Pinter, 2006). For instance, learners can be exposed to and can start acquiring sounds that are not part of their mother tongue.

As a starting point, this study aims at determining if English as a foreign language (EFL) young learners change their performance when following instructions after being exposed to an audiovisual materials-based teaching strategy and identifying what they think about this type of teaching technique.

\section{Theoretical Framework}

When talking about young learners, what must be taken into account is that this term covers a large chronological age span: from three years old to 15 (Nunan, 2010, p. 2). Pinter (2006) proposes an educational definition according to the years of schooling: Children 
typically start preschool at the age of 3-4 years, which is the group that this research focuses on. Table 1 shows some of the capacities of this group.

Table 1. Children: The First Age Group (Adapted From Pinter, 2006)

\begin{tabular}{|c|c|c|}
\hline Education & Age & Capacities \\
\hline Preschool & $3-5$ & $\begin{array}{ll}\text { - } & \text { No formal learning experiences } \\
\text { - } & \text { No literacy skills } \\
& \text { Large differences among children } \\
& \text { regarding readiness for school }\end{array}$ \\
\hline
\end{tabular}

This is a group that Pinter (2006) prefers to call younger learners. Some of their characteristics are listed below:

- Generally, they understand meaningful messages but cannot analyze language yet.

- Lower levels of awareness about themselves as well as about the process of learning.

- Limited reading and writing skills, even in their first language.

- Generally, more concerned about themselves than others.

- Limited knowledge about the world.

- They enjoy fantasy, imagination and movement (adapted from Nunan, 2010; Pinter, 2006).

Although these characteristics are intrinsic to them, in some cases English is not a part of their daily lives. In Chile, English is taught as a foreign language, with little presence of the language outside the classroom. Moreover, teaching English from preschool is not compulsory, yet some researchers have stated that "when language learning begins earlier, it can go on longer and provide more practice and experience, leading ultimately to greater fluency and effectiveness" (Curtain \& Dahlberg, 2010, p. 428). Although each school in the country is free to include English as part of its curriculum from kindergarten to fourth grade (authorized by the Ministry of Education), just a few do it.

Moreover, the way English is taught to younger learners plays an essential role. Teachers must consider children's cognitive development and what they are capable of at that age (35). Linse (2005) points out that "teachers of young learners have two jobs: to provide care and to provide instruction. In order to provide the best possible instruction, you need to adjust educational experiences to meet the developmental stages of the individual child" (p. 
2). Instructions and how they are provided acquire great importance when teaching younger learners. Ur (1991) states that:

When introducing new material, we often need also to give explicit descriptions or definitions of concepts or processes, and whether we can or cannot explain such new ideas clearly to our students may make a crucial difference to the success or failure of a lesson. (p. 16)

It becomes key then to be clear enough when providing instructions, since learning is at stake. This is one of the main reasons this action research focuses on a specific way of giving instructions to EFL younger learners. Ur (1991) defines instructions as "the directions given to introduce a learning task that entails some measure of independent student activity" (p. 16). Considering that instructions come from the teacher, Nunan (1991) highlights that "teacher talk is central in the language class for classroom organization and for the process of acquisition" (p. 189). Thus, the input and instructions provided have to be comprehensible enough as part of the language acquisition process (Linse, 2005; Liruso \& Villanueva de Debat, 2003). Besides, instructions have to be varied (Linse, 2005; Nunan, 2010); they have to be clear, brief and, for instance, must include the use of visual aids, concept checking questions, or pre-task demonstrations. By exposing learners to audiovisual materials in this study, instructions complied with what the literature states: Not only do audiovisual materials serve the purpose of making instructions clearer, but they also provide pre-task demonstrations and key vocabulary.

If we consider that most younger learners at this age have no literacy skills (Pinter, 2006), the way teachers give instructions and demonstrate how tasks have to be done can help to carry out successful language activities. Dörnyei (as cited in Ellis, 2002) points out the importance of tasks being presented in a way that motivates students. Ellis (2002) proposes that a way to get students' attention is by asking them to observe a model of how to perform a task. Coffey (2013) states that when a teacher demonstrates a task that students are expected to do on their own, modelling occurs. Furthermore, Haston (2007) highlights that "when used appropriately, teacher modelling for student imitation is a useful tool" (p. 26). It is important that when teachers model, they provide visual, auditory, kinesthetic, and tactile means for illustrating important aspects of the task (Intel Corporation, 2012). The more input learners receive when being modelled, the richer and easier the understanding of instructions will be. It is key that we have all our students' attention before a task (Musthafa, 2010; Ur, 1991).

Modelling must be used as part of the classroom routine, especially with younger learners who need to develop a sense of familiarity. Kang Shin (2006) states that "young learners function well within a structured environment and enjoy repetition of certain routines and activities. Having basic routines in the classroom can help to manage young learners" 
(p. 5). Besides, Touhill (2012) points out that "all children need a measure of routine and predictability to their day [for] it provides a significant sense of certainty and security" (p. 1).

In regard to the use of visual aids, it is important to consider the learning styles of the younger learners. For instance, Scrivener (2011) states that some people "may respond best to seeing things (visual) while others learn best when they can touch and feel tangible, physical objects (kinesthetic)" (p. 85). If we consider the younger learners' characteristics proposed by Nunan (2010) and Pinter (2006), we could state their main learning style is the visual one, which is defined as the style in which a person learns better visually (Silverman, 2005). Visual learners (also known as visual-spatial learners) think primarily in images and have visual strength (Silverman, 2005). According to Hindal (2014), "through the visual learning system, the learner recognizes objects, distinguishes sizes and shapes, perceives depth, notes color, and uses visual-spatial awareness to estimate where he is" (p. 557). In other words, for visual learners, as these younger learners are, it will be less difficult to recognize or associate pictures to key vocabulary for instance, for it is the visual aspect that helps them the most.

Furthermore, younger learners nowadays could be considered as part of the generation whose 60 percent are today visual or visual-kinesthetic learners (Jukes et al., 2010). Likewise, Krčelić and Skledar Matijević (2015) state that "today's students live in a predominately visual world, exposed to the media, technology and an overabundance of digital stimuli" (p. 110). Therefore, it makes sense that teachers use a varied set of visual materials in their lessons.

Considering that these younger learners do not understand English as they understand their mother tongue, some experiences inside the classroom may become more difficult. These learners will learn better when being exposed to audiovisual materials, for they are more realistic. Audiovisual aids do not only cater to the visual-spatial learning style but also the auditory (Ciara, 2016). However, they must be used carefully in the classroom. Aids have to serve the classroom and curriculum objectives. As Daniel (2013) points out, audio-visual aids:

- Help to avoid excessive, empty, and meaningless verbalization in teaching English.

- Help students to form clear and accurate concepts in English.

- Make teaching and learning effective.

- Provide variety to teaching.

- Provide interest and inspiration.

- Clarify the subject-matter.

- Save time and energy. (p. 3811) 


\section{Method}

Conceived as action research, this study was conducted to improve the quality of teaching inside the classroom (Mason, 2002). The understanding of instructions was an issue that needed to be addressed in this specific context.

\section{Research Problem}

EFL kindergarten learners must develop fundamental skills, which are also crosscurriculum; coloring, cutting, or following instructions are among them. Although most of the learners who were the focus of this study followed instructions appropriately, still a considerable number of learners followed neither instructions nor the modelling given when running the activities. Oral instructions (in English or Spanish), modelling, and even concept checking questions did not seem to make instructions comprehensible enough. Regardless of the different strategies used to make instructions clearer, students still struggled to follow commands for the completion of a language task. Therefore, the research question is: If I support with audiovisual materials the way I give instructions to kindergarten young learners, will it improve the learners' understanding of instructions?

\section{Research Objectives}

The general objective was to implement an audiovisual materials-based teaching strategy to identify a change in kindergarten learners' understanding of instructions when doing language tasks in the context of a semi-public school in Chile.

The specific objectives were: (a) to identify learners' group performance regarding their ability to follow instructions as a result of the implementation of an audiovisual elementsbased teaching strategy and (b) to analyze learners' attitudes towards their experience of being exposed to an audiovisual materials-based teaching strategy as a support for giving instructions.

\section{Participants}

The participants are eighteen EFL kindergarten learners from a semi-public school in San Carlos, Chile. This school is owned by a private educational corporation with funding from the government. Some of the learners' characteristics are:

- $\quad$ Eight girls and 10 boys (4-5 years old).

- Part of the generation whose 60 percent are today visual or visual-kinesthetic learners (Jukes et al., 2010). 
- Some had been exposed to English previously, approximately 52.5 hours in prekindergarten.

- Per week, they have three 45-minute English lessons (app. 76.5 hours per year).

The participants were observed and assessed in each session of this intervention regarding the first specific objective. Besides, a randomly-selected sub-sample of eight learners, plus a volunteer, ${ }^{1}$ was considered for the second specific objective.

\section{Research Procedure}

Within a three-week time frame, this study looked at how the use of an audiovisual materials-based teaching strategy helped to support the giving of instructions, thus the change in students' understanding of instructions. In six sessions, learners were exposed to this strategy. For instance, in tasks in which they had to cut or color, an audiovisual image shown by a projector (e.g., videos or flashcards) showed them what they had to do. Each action research session lasted 45 minutes ( 4.5 hours in total). Table 2 shows the activities and audiovisual materials employed for each session.

Table 2. Activities and Audiovisual Materials for Each Session

\begin{tabular}{|c|l|l|}
\hline Session & \multicolumn{1}{|c|}{ Activity } & \multicolumn{1}{c|}{ Audiovisual materials } \\
\hline $\mathbf{1}$ & Match and color the objects (listening) & $\begin{array}{l}\text { Flashcards, images (see } \\
\text { Figure 1), and modelling }\end{array}$ \\
\hline $\mathbf{2}$ & $\begin{array}{l}\text { Cut and glue pictures according } \\
\text { to a story (storytelling) }\end{array}$ & GIF (designed by the teacher) \\
\hline $\mathbf{3}$ & $\begin{array}{l}\text { Cut and glue according to } \\
\text { instructions (listening) }\end{array}$ & Videos \\
\hline $\mathbf{4}$ & Cut and color (listening) & Flashcards and videos \\
\hline $\mathbf{5}$ & $\begin{array}{l}\text { Matching game and TPR } \\
\text { activity (listening) }\end{array}$ & $\begin{array}{l}\text { GIF (designed by the } \\
\text { teacher) and videos }\end{array}$ \\
\hline $\mathbf{6}$ & $\begin{array}{l}\text { Game, match and color numbers } \\
\text { according to instructions (listening) }\end{array}$ & Videos \\
\hline
\end{tabular}

Note. $T P R=$ Total physical response, $\mathrm{GIF}=$ Graphic interchange format

In each session, one of the research-practitioners and co-author of this paper assessed with an instrument the learners' performance regarding their understanding of instructions,

Due to time constraints, the intention of asking for more volunteers was not doable. 
which were individually assessed by a rating scale that was part of the aforementioned instrument. For instance, if there were two instructions in a session, each one required a rating scale. Figure 1 shows part of the audiovisual material that was created.

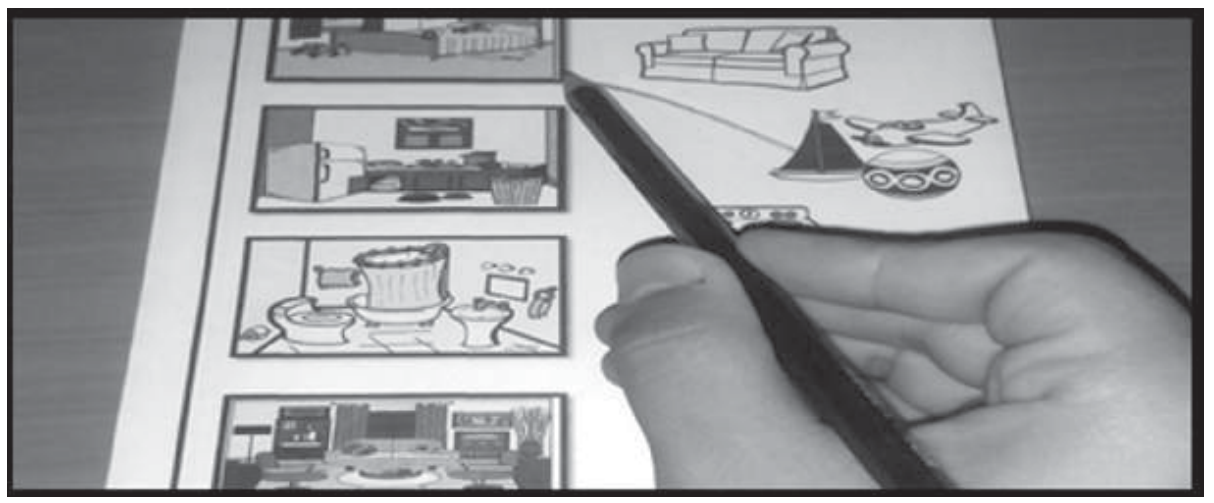

Figure 1. Sample Image From the Audiovisual Materials (Own Creation)

\section{Data Collection Instruments}

Lesson observation report (see Appendix 1). Regarding students' group performance, the understanding of instruction was assessed by the participants' performance after an instruction was given. The research practitioner filled out this instrument after each instruction, considering aspects such as oral instructions, modelling provided (by the teacher or a peer learner), use of concept checking questions, and a rating scale that was part of this instrument, for the assessment of the learners' performance with four performance levels: the student follows the instruction accurately, partially, poorly, and does not follow the instruction. Each performance level had got a descriptor. For instance:

Accurately: The students follow the instruction carefully and correctly, regardless of their possible psychomotor limitations due to their age. For instance, if they have to color a circle with the color blue, the students color within the lines (as well as possible) and the right color (and not light blue, for example).

Likert scale (see Appendix 2). Once the six sessions were implemented, a Likert scale activity was carried out on nine learners. This instrument aimed at gathering their attitudes towards the audiovisual materials-based strategy to inform specific objective 2. Due to the participants' age, literacy skills are barely developed (Nunan, 2010), so answer elaboration is seen as an overwhelming challenge for them. This is the main reasoning for choosing 
the Likert scale instead of another instrument. Besides, the Likert scale is more suitable for having a clear idea of students' attitudes regarding the exposure to the teaching strategy. An attitude will be understood as a pre-disposition or inclination to answer consistently in favor or not, ${ }^{2}$ in this case, of the teaching strategy.

Considering the students' barely developed literacy skills, we decided to carry out this instrument activity in Spanish to make it understandable. Statements ${ }^{3}$ were read to the participants, and they had to choose the symbol that represented their attitude toward what was being read.

- A hand with a thumb up = Yes

- An open hand $=$ The learner does not know or remember

- $\quad$ A hand with a thumb down $=$ No

\section{Data Analysis Techniques}

In regard to the analysis of the data, techniques were used according to each instrument. Firstly, for the lesson observation report the data were analyzed considering two elements: mean score and frequency of values. The mean score served to establish students' score in order to compare their progress during the implementation of this teaching strategy. In regard to frequency, this was collected and then analyzed per session. Each instruction reported was assigned a score (according to the lesson observation report), then with these results a mean score per session was obtained. Consequently, once all the results were gathered, a comparison was made with the mean scores to see how students were at the beginning and at the end of this exposure to the teaching strategy.

In the case of the Likert scale activity, the results were analyzed following the frequency of the answers given to identify the students' attitudes towards this teaching strategy. According to the frequency of the answers, percentages are displayed in each statement to show how students' responses stood after this intervention.

\section{Findings}

\section{Specific Objective 1}

Findings from each session shall be shown based on an analysis of frequency (percentage) and mean score.

As defined by Merriam-Webster Dictionary.

If necessary, statements were said more than once or paraphrased. 
In Session 1, students got a worksheet with a matching item and then had to color certain objects according to the instructions given by the teacher, which were supported by the use of static images as the audiovisual support for the session in which students were practicing the topic of the parts of a home: a house, its rooms and the corresponding objects. They had to match an object with the corresponding room where it belongs. Eventually, they had to color these objects following the teacher's instructions. Figures 2 to 4 show the findings from Session 1 regarding frequency.

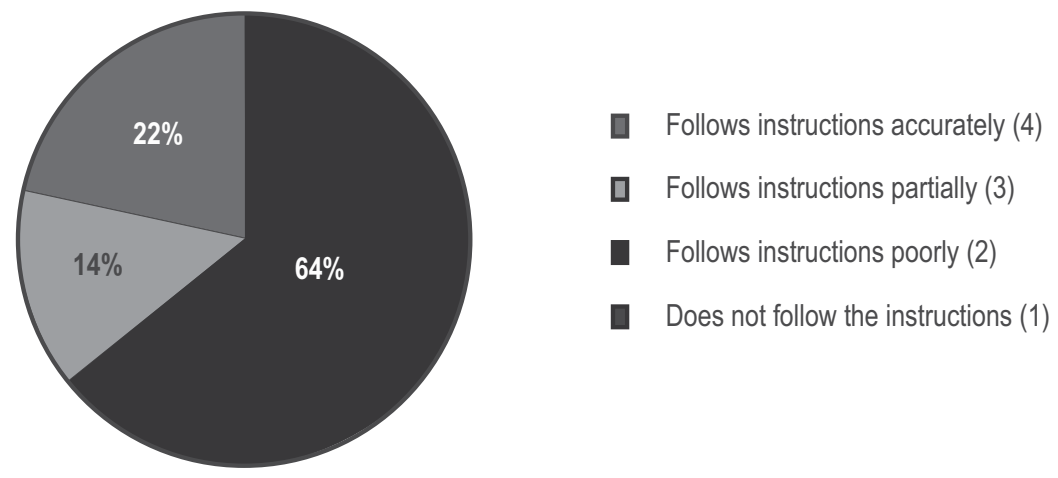

Figure 2. Frequency Instruction 1, Matching Exercise, Session 1

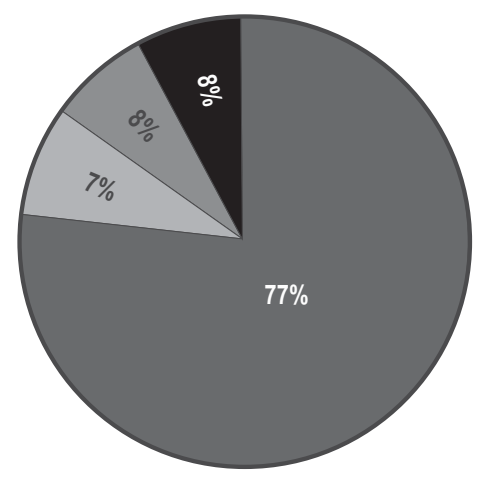

- Follows instructions accurately (4)

- Follows instructions partially (3)

Follows instructions poorly (2)

- Does not follow the instructions (1)

Figure 3. Frequency Instruction 2, Color an Object, Session 1

As Figure 2 shows, more than half of the learners followed instructions accurately, although a significant percentage $(36 \%)$ did it either partially or poorly. However, as Figures 3 and 4 show, the number of students who followed these instructions (2 and 3) accurately 


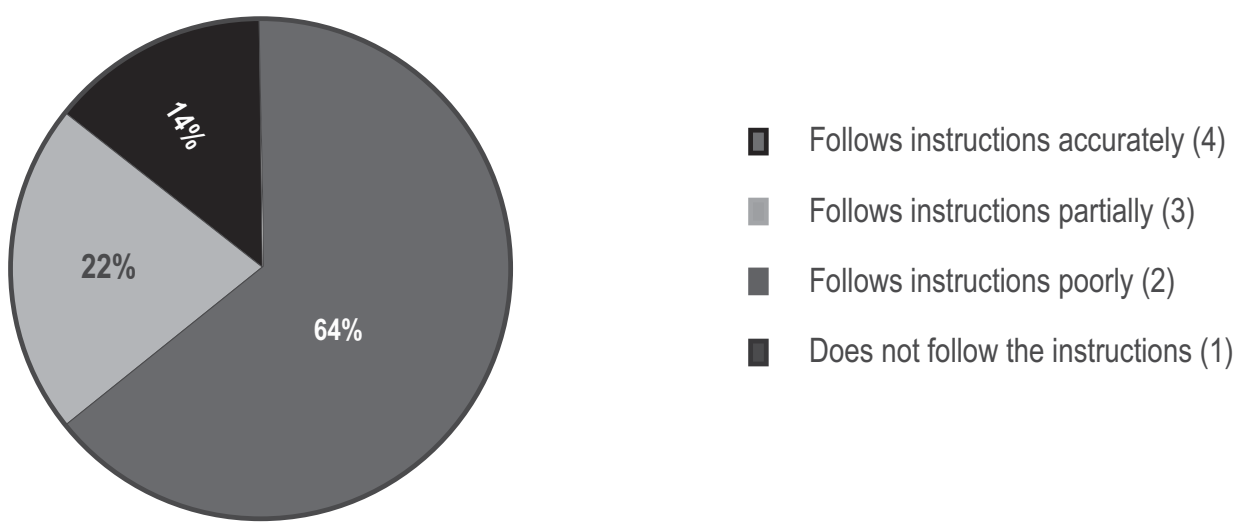

Figure 4. Frequency Instruction 3, Color an Object, Session 1

or partially increased ( $84 \%$ and $86 \%$ respectively). This may be due to the familiarity students had with the type of task (coloring), whereas matching was a task learners were recently doing in the subject.

Nonetheless, in Instruction 3 it can be seen that two students did not follow instructions $(14 \%)$, which among the three instructions is the highest percentage regarding this value. One of the learners did not stay on task due to misbehavior, and the other started doing the task before instructions were given.

In Figure 5, the mean scores per session and overall are shown in order to compare students' group performance within Session 1.

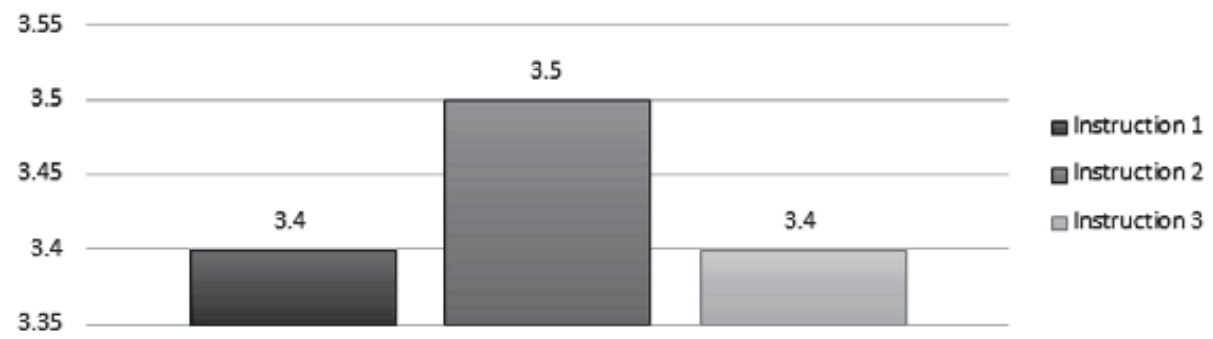

Figure 5. Mean Score per Instruction, Session 1 
The mean scores are closer to the value of partially rather than accurately, so it could be said that the students' performance as a group was appropriate.

In Session 2, there were only two instructions. The main resource was a worksheet in which students had to cut out a set of flashcards (family members) and then stick them on, according to the information in a story read by the teacher (storytelling). The audiovisual materials for the session were two GIFs, shown by a projector that modelled what the students had to do.

All participants followed Instruction 1 accurately and as for Instruction 2, the group's performance decreased with two students (15\%), being in the value of partially. Both students started to work later than their classmates, as observed during the monitoring of the activity.

Opposite to what happened in Session 1, in this case the final mean scores were closer to the value of accurately, with a 3.9. As the data show, the use of audiovisual materials, such as GIFs, represents an improvement in the students' response rate when compared to Session 1, when only static visual aids were used. Dörnyei (2001) highlights the importance of tasks being presented in a way that motivates learners.

For Session 3, the task was a listening activity in which students were asked to cut out a set of flashcards (the topic was pets) and then stick them on according to what the teacher said. From seven instructions (Instruction 1 asked students to cut out a set of flashcards; the other instructions asked students to glue each pet according to the instructions), four were assessed by the lesson observation report. The audiovisual materials were two videos (with and without audio) that modelled what learners had to do.

Again, students managed to achieve an accurate performance when following Instruction 1 of this session (100\% in the accurately value) due to the familiar task they had to perform. Nonetheless, in Instruction 2 the situation was different, with $88 \%$ of the students following the instruction accurately. During this session one of the students did not follow Instruction 2 because he started behaving disruptively, so after some incidents regarding his classmates' safety, he had to be taken out of the classroom as a precaution, thus he was not included in the report of this instruction.

Without any distractor, students seemed to work according to what was expected of them upon receiving the next command given by the teacher. Students managed to work accurately during Instruction $3(100 \%)$. Videos seemed to be of great help when making students follow the instruction, especially if familiarity with the task is considered. Nonetheless, in Instruction 4 a similar situation as in Instruction 2 occurred: While most participants (88\%) followed the instruction accurately, some did it partially $(6 \%)$ or poorly $(6 \%)$, who were participants that started to work later after Instruction 4 had been given.

Students kept a performance that is near to the value of accurately, with a mean score that could be approximated from 3.85 to 3.9 (mathematically speaking), resulting in a similar 
score as in Session 2. Again, learners' performance changed positively in comparison to Session 1. More explicit than GIFs, videos acted as modelling, which according to Ellis (2002) is a useful way to get the students' attention to know how to perform a task.

In regard to Session 4, learners decreased their performance. Due to several reasons such as misbehavior or students taking longer to do the task, not all the participants followed the instructions as they would normally have done. The main task in this session corresponded to the designing of the mask of a pet that students were assigned at random. Instructions were two; one for each step of the task (cutting and then coloring). Regarding the audiovisual materials, learners were exposed to two videos and flashcards that showed them what and how they had to do it, with previous instructions given orally.

In Instruction 1, more than half of the learners worked accurately ( $76 \%)$. Notwithstanding, regarding the partially $(12 \%)$ and poorly $(12 \%)$ values, two students started later than the rest of the class, which is unusual in this group. Both participants did what they were told, but when time was almost running out.

The same frequency was observed in Instruction 2, which illustrates the way of working that students usually demonstrate inside the classroom. However, participants in the value of partially followed the teacher's command later during the task, or, in the case of two of them, using more colors than the ones assigned and shown during the instructions for the task.

Although the mean scores were lower than in the previous sessions, learners can still be found near the value of accurately rather than partially, which shows that compared to what was seen in Session 1, learners indeed were improving their performances when following instructions.

When giving instructions, the use of two different audiovisual materials did not prove to be more effective than using only one or two of the same type (GIFs and videos technically share more similarities than with static images). Therefore, it could be assumed that more varied audiovisual materials when giving instructions did not guarantee a change in students' group performance. This situation may be explained by what Touhill (2012) points out about routines and materials: if we constantly change them, we risk the benefit students may get with more familiar materials.

During Session 5, students were asked to do two activities (both TPR). Instructions were given with the support of a GIF and a video. In both activities, the audiovisual materials modelled what learners had to do.

The particularity of the audiovisual materials used for this session is that a peer from another kindergarten group was recorded (with the mother's consent) while modelling the task. What we can glean from the data is that instructions supported by these materials were still of great help for improving students' performance when doing these tasks. In both 
instructions, all learners were found in the accurately (100\%) value. Regardless of a certain familiarity they might have had with the TPR activities, one of the tasks was different, since it included the use of realia (e.g., sauce pan, blanket) for completing it. Based on the results, the new elements introduced in the activities did not affect negatively in any case the learners' performance.

According to the results from this session, students seemed to perform better when doing engaging and familiar tasks, even if new aspects were included. Besides, instructions appeared to be more effective when being supported by videos or GIFs rather than only static images, for they act as modelling which, as mentioned before, is a useful way to get the class' full attention (Ellis, 2002). Moreover, the familiarity with the activities played an important role, as stated by Touhill (2012).

Finally, in Session 6 the tasks were two: A game and a listening/matching activity in which students had to color and match some numbers accordingly to what the teacher said. In regard to the audiovisual materials, this lesson considered the most effective audiovisual material they had used so far: videos. Two videos showed the participants what they had to do in each task.

As seen in previous lessons, students seemed to perform better when playing games as a way of practicing the vocabulary seen. All participants followed Instruction 1 accurately, and again this might have been strictly related to the activity and the type of audiovisual materials employed. Up to this point in the semester, students were quite accustomed to playing different games, so once they saw the video, they immediately understood the activity. Besides, to see if instructions were indeed comprehended, concept check questions (CCQs) were used for clarification. Nonetheless, after the game learners had to do the following task, which was the listening/matching activity. In the three instructions that followed (color numbers composed of two digits, e.g., 12), their performance was not as good as in Instruction 1, yet they still managed to be near the value of accurately. In Instruction 2, 80\% of the participants followed it accurately, with $20 \%$ in the value of partially. As for the case of Instruction 3, the percentage of participants following the instruction accurately increased (93\%), with only one participant found in partially (7\%). Finally, in regard to Instruction 4, $87 \%$ of the participants followed this instruction accurately and $13 \%$ partially.

This decrease in their performance, as observed while monitoring, was mainly due to learners not completing the task assigned in each instruction. They had to match and color each number said by the teacher, yet not all of them did it completely. This can be explained by two issues. Some of the students did not want to color the entire number, and others were not sure if they had to color either the two digits or just one of them (as in 12, for instance). Learners at this age do not have a complete understanding of numbers for they have recently started learning them (Nunan, 2010; Pinter, 2006). However, instructions were 
not as clear as they should have been during this session, for the audiovisual material for these instructions was shown once. Nonetheless, regardless of the aforementioned issues, students still managed to be near the value of accurately in each instruction.

In order to identify if their performance had improved during this intervention, Figure 6 displays a comparison among all the mean scores per session.

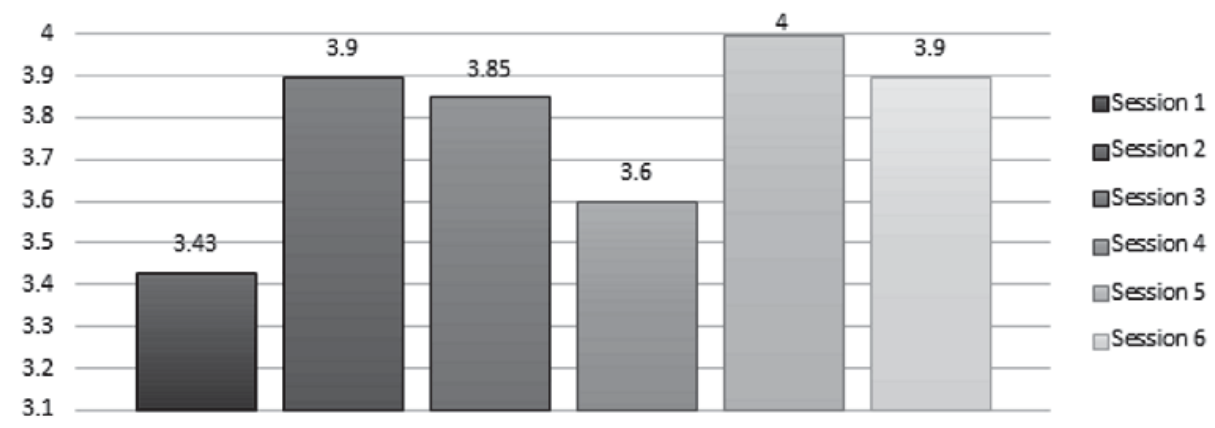

Figure 6. Comparative Chart: Final Mean Scores per Session

As Figure 6 shows, improvement at the end of the intervention was not linear. Notwithstanding, there was indeed an improvement if we compare the mean score from Session 1 and the one from Session 6. From the second session onwards, the final mean scores were closer to the value of accurately rather than partially (as in the case of Session 1). From these results, it could be stated that there is a positive change in the students' group performance when following instructions, which translates into better scores as Figure 6 shows. This may be explained in part due to the use of audiovisual materials that made students understand instructions more clearly and engagingly. Finally, audiovisual materials may have had a key role in the understanding of instructions, especially if we consider that they help students to form clear and accurate concepts in English and they provide interest (Daniel, 2013).

\section{Specific Objective 2}

Regarding the specific objective 2, results from the Likert scale were analyzed based on the frequency shown in percentages. The analysis is divided into the statements from the Likert scale. In Table 3, the findings from each statement are shown in detail. 
Table 3. Frequency of Values From the Likert Scale

\begin{tabular}{|c|c|c|c|}
\hline Statement & $\begin{array}{c}\text { Yes } \\
\%\end{array}$ & $\begin{array}{c}\text { I don't know or } \\
\text { remember } \\
\%\end{array}$ & $\begin{array}{l}\text { No } \\
\%\end{array}$ \\
\hline $\begin{array}{l}\text { 1. I understand the teacher when he shows images } \\
\text { or videos }\end{array}$ & 100 & & \\
\hline $\begin{array}{l}\text { 2. It is easy to follow instructions when the teacher shows } \\
\text { images or videos. }\end{array}$ & 89 & & 11 \\
\hline $\begin{array}{l}\text { 3. My classmates understand better when the teacher } \\
\text { shows images or videos. }\end{array}$ & 67 & 11 & 22 \\
\hline $\begin{array}{l}\text { 4. There is enough time to follow each instruction } \\
\text { when the teacher shows images or videos. }\end{array}$ & 45 & 33 & 22 \\
\hline $\begin{array}{l}\text { 5. I can finish my task when the teacher shows images } \\
\text { or videos. }\end{array}$ & 89 & & 11 \\
\hline $\begin{array}{l}\text { 6. I do my tasks better when the teacher shows images } \\
\text { or videos }\end{array}$ & 78 & 22 & \\
\hline $\begin{array}{l}\text { 7. The tasks are easier to do when the teacher shows } \\
\text { images or pictures. }\end{array}$ & 89 & 11 & \\
\hline $\begin{array}{l}\text { 8. When the teacher shows images or videos, } \\
\text { my classmates' tasks are better. }\end{array}$ & 78 & 11 & 11 \\
\hline
\end{tabular}

All the learners seemed to think they understood the teacher whenever images or videos were shown before giving the corresponding instructions. Regardless of their age (4-5 years old), they were quite aware of the strategy and its use for helping them understand instructions appropriately.

From the whole sub-sample, in Statement 2 only one participant (11\%) did not agree with the statement. Nonetheless, the rest of the sample (89\%) agreed that instructions were easy to follow when being exposed to the teaching strategy.

When being asked about their viewpoints on their classmates' understanding the teacher, most of them (67\%) agreed that they did. Findings regarding the specific objective 1 match 
to some extent with what students answered in this statement, even with the ones that did not agree with it.

Regarding Statement 4, this one was the most heterogeneous according to the learners' responses. Less than half of them (45\%) stated that there was enough time, and a significant percentage ( $55 \%$ in total) did not remember/know or agree with the statement. Although it is worrying that students perceived there was not enough time, evidence contradicts this issue, since most of the students were able to complete their activities within the timeframe given correspondingly.

Although students tended to think there was not enough time to follow each instruction, most of them ( $89 \%$ ) believed that they could complete their tasks when being exposed to this teaching strategy, as shown by Statement 5 . Based on the findings from the lesson observation report, their answers match what was observed and assessed during the intervention.

In regard to Statement 6, more than half of the sample (78\%) agreed with this statement, and the rest $(22 \%)$ did not know or remember. As seen in the results from specific objective 1 , their tasks were better than before the intervention.

Almost the entire sample (89\%) agreed that tasks were easier to do when being exposed to this teaching strategy (Statement 7), which, as results show, seemed to be the case. Once this strategy became a routine to the students, most of them followed each instruction faster and accurately, which only translated into a benefit for the lesson development.

Finally, in Statement 8 most of the learners from this sample (78\%) agreed that not only their tasks were better, but also their classmates', which shows the perception they had regarding their peers' performance when being exposed to this strategy. Findings previously shown in this paper show that their viewpoints in this statement relate to the results obtained by the teaching strategy.

\section{Conclusions}

As findings show, improvement can be seen in the final results, even if it is slight in some sessions. Participants clearly performed better with familiar tasks, which may be due to the sense of certainty and security routines provide (Touhill, 2012). Besides, it is important to highlight that these results were achieved when learners were exposed to videos, which seemed to be more appealing and engaging since findings show that students followed instructions accurately, possibly due to clearer instructions given through the audiovisual materials. Therefore, it can be concluded that this strategy had a positive change on the learners' performance: improving their ability to follow instructions and their pace when following them. 
Furthermore, this strategy became a routine in the lessons. At first, learners took their time to get familiarized with the strategy, but in the following sessions they knew what they had to do in each task. This could lead to learners feeling relaxed and self-confident about what they do in the English lessons, which makes learning and language acquisition more likely to happen (Krashen, 1982; Martínez Rincón, 2014).

As seen in the findings from the Likert scale, learners regarded this teaching strategy as beneficial for the quality of their own tasks and for their classmates as well. Although students at this age are more concerned about themselves than the others (Nunan, 2010), when being asked about their classmates and their work, most of them were able to provide an answer regarding those questions. They seemed to be aware not only of their work and how it had improved after the use of the audiovisual materials, but also of their classmates'. Therefore, it could be assumed that participants saw this strategy as an improvement not only in the lessons but also for their own development as learners.

As for the students' different rhythms of learning and working, it can be concluded that the strategy allowed them to work evenly, with no significant differences in their performances. The type of aids when giving instructions was different and varied in the six sessions to cater to the different learning styles. By supporting instructions, this strategy addressed the diversity these students represented. As Nunan (2010) states, diversity can be a strength; "if you can draw on diversity, then your teaching, and the consequent learning opportunities of the students, will be all the richer" (p. 11). If we want an inclusive classroom, it is our duty to plan and teach, thinking about all our students and their needs, which will lead eventually to more meaningful learning.

\section{Limitations of the Study and Further Studies}

Since this is a context-specific action research study, results cannot be generalizable. It is the reader who has to select those findings that would be a contribution to his/her own teaching context.

Finally, an important aspect to have in mind has to do with students with special needs, since there was no measurement in this study to assess if the strategy really helped this type of learners. Further studies could be conducted to see specific cases and study how learners with special needs perform and respond to this strategy. It would also be advisable to conduct this study together with a team of psychologists and special education teachers.

\section{References}

Cameron, L. (2001). Teaching language to young learners. Cambridge, UK: Cambridge University Press. https://doi.org/10.1017/CBO9780511733109. 
Ciara, K. (2016, May 14). The benefits of using audio-visual aids in teaching [Web log post]. Retrieved from https://www.techprevue.com/audio-visual-aids-benefits-teaching/.

Coffey, H. (2013). Modeling. Retrieved from http://www.learnnc.org/lp/pages/4697.

Curtain, H., \& Dahlberg, C. A. (2010). Languages and children. Making the match: New languages for young learners, Grades K-8 (4th ed.). New York, US: Pearson.

Daniel, J. (2013). Audio-visual aids in teaching of English. International Journal of Innovative Research in Science, Engineering and Technology, 2(8), 3811-3814.

Dörnyei, Z. (2001). Motivational strategies in the language classroom. Cambridge, UK: Cambridge University Press. https://doi.org/10.1017/CBO9780511667343.

Ellis, R. (2002). The methodology of task-based teaching. Retrieved from https://www.kansai-u. ac.jp/fl/publication/pdf_education/04/5rodellis.pdf.

Haston, W. (2007). Teacher modeling as an effective teaching strategy. Music Educators Journal, 93(4), 26-30. https://doi.org/10.1177/002743210709300414.

Hindal, H. S. (2014). Visual-spatial learning: A characteristic of gifted students. European Scientific Journal, 10(13), 557-574.

Intel Corporation. (2012). Instructional strategies: Modeling. Retrieved from https://www.intel. $\mathrm{com} /$ content/dam/www/program/education/us/en/documents/project-design/strategies/instructionalstrategies-modeling.pdf.

Jukes, I., McCain, T., \& Crockett, L. (2010). Understanding the digital generation: Teaching and learning in the new digital landscape. Thousand Oaks, US: Corwin Press.

Kang Shin, J. (2006). Ten helpful ideas for teaching English to young learners. English Teaching Forum, 44(2), 2-13.

Krashen, S. D. (1982). Principles and practice in second language acquisition. Oxford, UK: Pergamon Press.

Krčelić, P., \& Skledar Matijević, A. (2015). A picture and a thousand words: Visual tools in ELT. In T. Kužić, D. Pleše, \& A. Plićanić Mesić (Eds), Proceedings of the Eighth International Language Conference on the Importance of Learning Professional Foreign Languages for Communication Between Cultures 2015 (pp. 110-114). Zagreb, HR: CROSBI.

Lightbown, P. M., \& Spada, N. (2013). How languages are learned. Oxford, UK: Oxford University Press.

Linse, C. T. (2005). Practical English language teaching: Young learners. New York, US: McGraw-Hill.

Liruso, S. M., \& Villanueva de Debat, E. (2003). Giving oral instructions to EFL young learners. Encuentro: Revista de Investigación e Innovación en la Clase, (13-14), 138-147.

Martínez Rincón, L. (2014). El efecto del filtro afectivo en el proceso de enseñanza-aprendizaje de una lengua extranjera (inglés) y actividades para su reducción en educación primaria (Tesis de maestría). Universidad de Valladolid, España.

Mason, J. (2002). Qualitative researching (2nd ed.). London, UK: Sage Publications.

Musthafa, B. (2010). Teaching English to young learners in Indonesia: Essential requirements. Educationist, 4(2), 120-125. 
Nunan, D. (1991). Language teaching methodology: A textbook for teachers. Upper Saddle River, US: Prentice Hall.

Nunan, D. (2010). Teaching English to young learners. Anaheim, US: Anaheim University Press.

Pinter, A. (2006). Teaching young language learners. Oxford, UK: Oxford University Press.

Scrivener, J. (2011). Learning teaching: The essential guide to English language teaching (3rd ed.). Basingstoke, UK: Macmillan Education.

Silverman, L. K. (2005, November 24). Upside-down brilliance: The visual-spatial learner. Retrieved from http://pegy.org.uk/Upside-Down\%20Brilliance\%20-A4\%20pdf.pdf.

Touhill, L. (2012). Continuity of learning. NQS PLP e-Newsletter, 46. Retrieved from http://www. ecrh.edu.au/resources/detail/index/nqs-plp-e-newsletter-no.46-2012-continuity-of-learning.

Ur, P. (1991). A course in language teaching: Practice and theory. Cambridge, UK: Cambridge University Press.

\section{The Authors}

Gemalli Ulloa Salazar holds a BA in education and teaching of English and an MA in innovation of teaching, learning, and assessment of English, both from Universidad de Concepción (Chile). He is currently working at Colegio Concepción de San Carlos in Chile.

Claudio Díaz Larenas holds a D.Ed. and an MA in linguistics. He also holds a BA in Education and teaching of English from Universidad de Concepción (Chile). He is the head of the master program, Magister en la Innovación de la Enseñanza, Aprendizaje y Evaluación del Inglés at Universidad de Concepción (Chile). 


\section{Appendix 1: Lesson Observation Report}

Date:

Hour:

$\mathbf{N}^{\circ}$ of Students:

\begin{tabular}{|c|c|}
\hline Type of task & \\
\hline Skill to be developed (e.g.: cutting, painting, etc.) & \\
\hline
\end{tabular}

Oral instructions given Yes No

\begin{tabular}{|l|l|l|l|l|l|}
\hline \multirow{2}{*}{ Modeling provided by: } & Teacher & \multirow{2}{*}{ Yes } & & \multirow{2}{*}{ No } & \\
& & & & & \\
\hline
\end{tabular}

\section{Use of audiovisual material}

\begin{tabular}{|l|l|}
\hline Yes & No \\
\hline & \\
\hline
\end{tabular}

\begin{tabular}{|l|l|l|l|l|}
\hline Use of CCQs & Yes & No & \\
\hline
\end{tabular}

\begin{tabular}{|c|l|l|l|l|l|}
\hline $\mathbf{N}^{\circ}$ & Student & Accurately (4) & Partially (3) & Poorly (2) & $\begin{array}{c}\text { Does not follow } \\
\text { instructions (1) }\end{array}$ \\
\hline 1. & & & & & \\
\hline 2. & & & & & \\
\hline 3. & & & & & \\
\hline 4. & & & & & \\
\hline 5. & & & & & \\
\hline 6. & & & & & \\
\hline 7. & & & & & \\
\hline 8. & & & & & \\
\hline 9. & & & & & \\
\hline 10. & & & & & \\
\hline
\end{tabular}

Comments: 


\section{Appendix 2: Likert Scale ${ }^{4}$}

Instructions: The teacher will read you some questions, and you will have to choose a hand that represents your opinion. Example: The hand with a thumb up represents that you agree with what it is being said; in other words, that you think it is true. The open hand means you do not know or you are not sure. On the contrary, the hand with the thumb down represents that you disagree with what the teacher is reading, which means you think it is not true.

\begin{tabular}{|l|l|l|l|}
\hline I understand the teacher when he shows images or videos. & & \\
\hline $\begin{array}{l}\text { It is easy to follow instructions when the } \\
\text { teacher shows images or videos. }\end{array}$ & a & \\
\hline
\end{tabular}

My classmates understand better when the teacher shows images or videos.

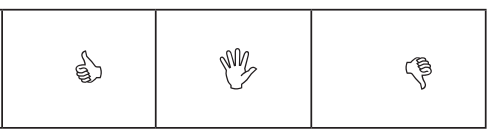

I do my tasks better when the teacher shows images or videos.

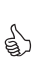

है।

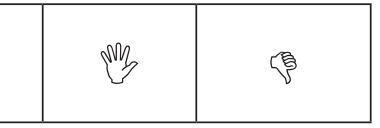

There is enough time to follow each instruction when the teacher shows images or videos.
क्षे

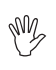

得

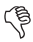

